\title{
Retinoid nutritional status differently affects the expression of Japanese quail retinoic acid receptor- $\beta$ isoform transcripts in a tissue-specific manner
}

\author{
Z W Fu, T Kubo ${ }^{1}$, K Sugahara ${ }^{1}$, T Noguchi and $\mathbf{H}$ Kato \\ Laboratory of Nutritional Biochemistry, Department of Applied Biological Chemistry, Graduate School of Agricultural and Life Sciences, \\ University of Tokyo, Bunkyo-ku, Tokyo, 113-8657, Japan \\ ${ }^{1}$ Faculty of Agriculture, Utsunomiya University, Mine-machi, Utsunomiya-shi, 321-8505, Japan \\ (Requests for offprints should be addressed to H Kato; Email: akatoq@mail.ecc.u-tokyo.ac.jp)
}

\begin{abstract}
We investigated the effects of vitamin A (VA) nutritional status on the levels of expression of retinoic acid (RA) receptor- $\beta$ (RAR $\beta$ ) gene in the various tissues of Japanese quail. VA deficiency caused a significant decrease in the mRNA levels of brain, liver, heart, lung and kidney $\operatorname{RAR} \beta 2 / \beta 4$, whereas no change was observed in the level of testis RAR $\beta 2$ transcript. In contrast, reduction in the RAR $\beta 1$ transcript caused by VA depletion was observed only in the lung, remaining unchanged in the other tissues. The administration of RA to the VA-deficient quail
\end{abstract}

rapidly induced the expression of $\mathrm{RAR} \beta 2 / \beta 4 \mathrm{mRNAs}$ in all the tissues examined, but RA increased the expression of RAR $\beta 1$ transcript in the liver, heart, lung and kidney at a lower magnitude. RA could not change the expression of the brain RAR $\beta 1$ transcript, while it induced the expression of the testis RAR $\beta 1$ mRNA in a temporal way. These results clearly indicate that VA nutritional status differently regulates the expression of $\operatorname{RAR} \beta 1$ and $\mathrm{RAR} \beta 2 / \beta 4$ transcripts in a tissue-specific manner.

Journal of Endocrinology (2001) 169, 281-290

\section{Introduction}

Retinol (vitamin A (VA)) is essential for normal growth, vision, reproduction and embryonic and fetal development, for the maintenance of numerous tissues, and for overall survival in many species. The indispensability of VA becomes clear by feeding VA-deficient ( - VA) diets to animals. In embryonic development, maternal VA deficiency during gestation leads to embryonic malformations including cleft palate and abnormalities of the eyes, heart, circulatory system and urogenital tract (Wilson et al. 1953). In postnatal life, VA deprivation causes many abnormalities including retarded growth, widespread substitution of keratinizing squamous epithelium, atrophy of several glandular organs, eye lesions and testis degeneration (Wolbach \& Howe 1925, Underwood 1984). These animals eventually die because of infection. The lesions can be reversed by VA administration, firmly confirming the importance of this vitamin as an essential factor in every aspect of life.

Retinoic acid (RA), a VA metabolite, is able to perform most of the actions of VA in vertebrates, because most VA-deficiency symptoms can be prevented or reversed by RA administration. Moreover, the action of RA is more vigorous or quicker than that of VA in many in vivo and in vitro instances (Heyman et al. 1992, Levin et al. 1992,
Lohnes et al. 1994, Mendelsohn et al. 1994b). Thus, it has been generally accepted that RA is the active form of VA. Recently, we also found that RA is more active than VA in the process of sexual maturation of Japanese quail (Fu et al. 1997b, 2000).

The biological effects of the RA signal are mediated through its specific nuclear receptors, which act as inducible transcriptional regulatory proteins and belong to the steroid/thyroid hormone superfamily of nuclear receptors (Giguerre et al. 1987, Petkovich et al. 1987, Evans 1988). There are two distinct classes of retinoid receptors: RA receptors (RARs), which are activated by both all-trans and 9-cis RA, and retinoid X receptors (RXRs), which bind to and are activated by 9-cis RA only. Each class consists of three subtypes of receptor $(\operatorname{RAR} \alpha, \beta, \gamma$; $\operatorname{RXR} \alpha, \beta, \gamma)$. From each gene, several isoforms are derived by alternative splicing and the usage of different promoters (Kastner et al. 1990, Leroy et al. 1991, Zelent et al. 1991). The functions of these receptors have been studied using transgenic mice with targeted disruption of a particular receptor or double receptors. Disruption of the single RAR $\alpha$ (Lufkin et al. 1993), RAR $\gamma$ (Lohnes et al. 1993) or RXR $\beta$ (Kastner et al. 1996) resulted in male sterility in homozygous knockout mice; these effects were similar to those observed in the male mice kept on a - VA diet. Compound null mutations of RARs led to lethality 
in utero or shortly after birth and to numerous developmental abnormalities (Lohnes et al. 1994, Mendelsohn et al. 1994b); most of them resembled those observed in the offspring of VA-deficient dams (Wilson et al. 1953). These studies strongly support the function of RARs serving as transcriptional transducers of the retinoid signal. Therefore, elucidating how VA nutritional status affects the expression of RARs and/or RXRs will help in understanding the physiological actions of VA.

The influences of VA depletion or repletion on the expression of RARs and RXRs have been examined in various tissues of adult mammals (Ul-Haq et al. 1991, Kato et al. 1992, Van Pelt et al. 1992, Verma et al. 1992, Gaemers et al. 1997, Akmal et al. 1998). Results from these studies demonstrated that, of RARs and RXRs, RAR $\beta$ was most sensitive to changes of VA nutritional status, suggesting that $\operatorname{RAR} \beta$ functions, at least partly, as a participant in the retinoid-signaling pathway. In birds, the effects of VA deficiency on the expression of RARs have been analyzed only in the very early stages of embryonic development, suggesting the importance of $\operatorname{RAR} \beta 2$ in the mechanism of the action of retinoids in early avian development (Kostetskii et al. 1996). What has remained unknown, however, are the molecular mechanisms of retinoid signal transduction pathways that are responsible for the essential physiological functions of VA in birds after hatching. We recently found that RAR $\beta$ is widely expressed in various tissues of adult Japanese quail (Fu et al. 2001). This result suggests that $\operatorname{RAR} \beta$ may play an important role in the maintenance of numerous tissues in Japanese quail.

The purposes of the studies described here were to determine how VA deficiency and retinoid administration affect the expression of RAR $\beta$ isoform transcripts in various tissues of Japanese quail, and to explore the relationship between the growth stages of birds and the effects of retinoid administration on $\operatorname{RAR} \beta$ gene expression.

\section{Materials and Methods}

\section{Animals and experimental design}

One-day-old male Japanese quail were housed in a brooder and maintained on continual illumination for 3 days, and then were subjected to a $14 \mathrm{~h}$ light: $10 \mathrm{~h}$ darkness cycle. Food and water were available at all times throughout the experiment. Three different diets, a - VA diet, a - VA diet supplemented with $5000 \mathrm{IU} / \mathrm{kg}$ diet of all-trans retinyl acetate (+VA diet), and a - VA diet supplemented with $4 \mathrm{mg} / \mathrm{kg}$ diet of all-trans RA (+RA diet), were prepared as described previously ( $\mathrm{Fu}$ et al. 2000). In the - VA diet, other nutrients except VA were sufficient to support normal growth. All three diets were prepared fresh weekly and stored at $-20{ }^{\circ} \mathrm{C}$ until use. All-trans retinyl acetate and all-trans RA were purchased from Wako Purechemical (Osaka, Japan) and Sigma Chemical Co. (St Louis, MO, USA) respectively.

In Experiment 1, 1-day-old quail were randomly divided into two groups (control and VA-deficient groups). The VA-deficient group was fed the - VA diet, while the control one was maintained on the +VA diet. To assess the degree of VA depletion in the VA-deficient group, serum VA and hepatic retinyl palmitate levels were determined at 7, 14, 17 and 21 days of age by HPLC as described previously (Fu et al. 1998, 1999). At 14 and 21 days of age, five birds from each group were killed by decapitation, immediately after which their tissues, including brain, liver, heart, lung, kidney and testis, were dissected and frozen in liquid nitrogen and stored at $-80{ }^{\circ} \mathrm{C}$ until analysis.

In Experiment 2, 1-day-old quail were fed the +VA or - VA diet for 21 days. At this time, five quail from each group were injected i.m. with $0.1 \mathrm{mg} \mathrm{RA}, 0.1 \mathrm{mg}$ VA or an equal amount of vehicle. RA and VA were dissolved in ethanol $(10 \mathrm{mg} / \mathrm{ml})$, and were diluted 5 -fold in rapeseed oil prior to injection. The quail were killed 3 or $8 \mathrm{~h}$ after treatment and their tissues were dissected and immediately frozen in liquid nitrogen, then stored at $-80{ }^{\circ} \mathrm{C}$ until analysis.

In Experiment 3, in order to deplete VA and RA as completely as possible, 1-day-old quail were fed the - VA diet for 2 weeks, then the +RA diet for 2 or 4 weeks, and finally the $-V A$ diet for 1 week. Then the quail were treated with VA, RA, or vehicle as described in Experiment 2. The quail were killed $3 \mathrm{~h}$ after treatment, immediately after which their tissues were dissected and frozen as described in Experiment 1.

All experiments were performed under the guidelines of the Animal Usage Committee of the Faculty of Agriculture, University of Tokyo.

\section{Lysate RNase protection assay}

A 425 bp segment of qRAR $\beta 2$ cDNA, which consisted of $9 \mathrm{bp}$ of $5^{\prime}$-untranslated region, all of the $\mathrm{A}$ and $\mathrm{B}$ domains and part (177 bp) of the $\mathrm{C}$ domain (corresponding to positions 18-443 bp, GenBank accession No. AF110730), was amplified by RT-PCR. To generate an antisense RAR $\beta$ cRNA probe, this 425 bp cDNA was subcloned into the pCR II vector (Invitrogen Carlsbad, CA, USA), linearized with HindIII restriction endonuclease, and transcribed by T7 RNA polymerase in the presence of $\left[\alpha_{-}{ }^{32} \mathrm{P}\right]$ UTP as described previously (Matsumura et al. 1996). We have confirmed that an assay using the antisense RAR $\beta 2$ cRNA probe can distinguish mRNA expression among different isoforms of qRAR $\beta$ ( $F u$ et al. 2001).

Levels of qRAR $\beta$ mRNA in tissues obtained from Experiments 1, 2 and 3 were analyzed by lysate RNase protection assay as described previously (Fu et al. 1997a, 2001, Kato et al. 1999). Briefly, tissues were homogenized 
in five volumes (w/v) of lysis buffer ( $5 \mathrm{M}$ guanidinium thiocyanate, $0 \cdot 1 \mathrm{M}$ EDTA, $0 \cdot 1 \mathrm{M}$ Tris, $\mathrm{pH} 7 \cdot 0,1 \%$ $\beta$-mercaptoethanol). The homogenate was centrifuged at $10000 \mathrm{~g}$ for $5 \mathrm{~min}$ at room temperature, and aliquots of $50 \mu \mathrm{l}$ supernatant were mixed with $5 \mu \mathrm{l}$ lysis buffer containing 250000 c.p.m. of probe. After overnight hybridization at $37^{\circ} \mathrm{C}, 500 \mu \mathrm{l}$ digestion buffer containing RNase $\mathrm{A}$ and RNase T1 were added, and excess probes were digested at $37^{\circ} \mathrm{C}$ for $30 \mathrm{~min}$. Twenty microliters $10 \%$ sodium N-lauroyl-sarcosinate and $5 \mu \mathrm{l}$ proteinase $\mathrm{K}$ solution (RNA grade; Gibco BRL, Rockville, MD, USA) were added, and tubes incubated at $37^{\circ} \mathrm{C}$ for $30 \mathrm{~min}$. The tubes were centrifuged for $2 \mathrm{~min}$ at room temperature. The supernatant and $500 \mu \mathrm{l}$ isopropanol were mixed, kept at $-20{ }^{\circ} \mathrm{C}$ for $30 \mathrm{~min}$, and then centrifuged for $15 \mathrm{~min}$. The precipitates were dried and resuspended in sample buffer. Hybridized RNA was size-separated on an 8\% acrylamide gel. To compare equivalent quantities of RNA, quail $\beta$-actin (120 bp) was used as an internal control.

\section{Data analysis}

Hybridized blots were imaged and analyzed using MacBAS-2000 (FujiPhoto Film, Tokyo, Japan). All values for mRNA levels are given as a relative value within tissue in an experiment. In cases where the S.E.M. is given, the means reflect five samples, and the statistical significance was determined by one-way or repeated measures ANOVA. Post hoc analysis was performed with Tukey's multiple comparisons test.

\section{Results}

$V A$ deficiency affects the expression of $q R A R \beta$ isoform $m R N A$ s in tissue/isoform-specific manners (Experiment 1)

Being fed the - VA diet for 14 days did not retard the growth of the quail, but significantly reduced their growth during the next 7 days $(P<0 \cdot 05)$ (Fig. 1). The process of VA depletion in plasma and liver of the - VA birds during this period is shown in Fig. 2. The VA in plasma ( $\mathrm{df}=4,24$; $F=330.6 ; P<0 \cdot 001)$ and total retinyl palmitate in liver $(\mathrm{df}=4,24 ; F=57 \cdot 4 ; P<0 \cdot 001)$ declined rapidly with age when the quail were fed the - VA diet, and both reached a not-detected level on day 21. In contrast, serum VA levels in the control group stayed almost constant (about $110 \mu \mathrm{g} / \mathrm{dl}$ ), and abundant storage of retinyl palmitate in the liver was also confirmed (data not shown).

Then, we examined how VA deficiency influences the expression of qRAR $\beta$ isoform transcripts in various tissues. Levels of qRAR $\beta$ isoform mRNAs were measured by the RNase protection assay in many tissues on day 14 and day 21, when the quail were under different degrees of VA deficiency. As illustrated in Fig. 3, two major bands were present in all tissues examined. They represented qRAR $\beta 1$ and $\beta 2$ transcripts respectively, according to our

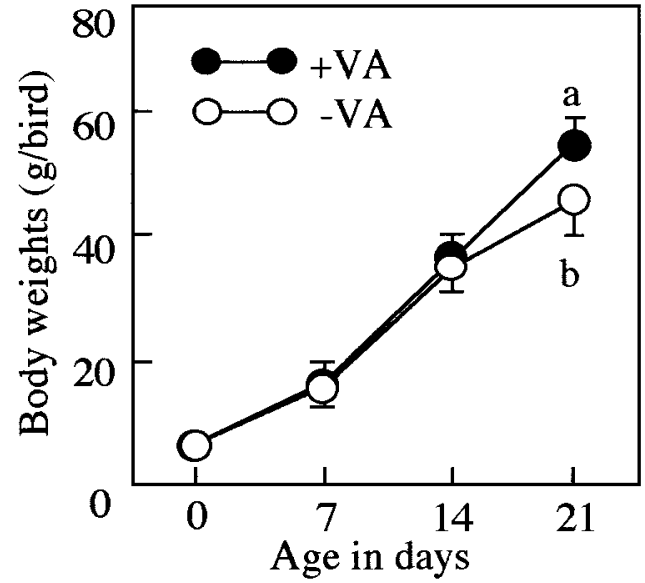

Figure 1 Feeding Japanese quail a $-\mathrm{VA}$ diet for 3 weeks retarded their growth. One-day-old quail were fed a - VA diet or this - VA diet supplemented with $5000 \mathrm{IU} / \mathrm{kg}$ diet of VA (+VA). Data represent means \pm S.E.M. $(n=5)$. Means not having the same letters within the same week differ significantly $(P<0 \cdot 05)$.

previous results (Fu et al. 2001). An additional, weak band existing between the $\beta 1$ and $\beta 2$ is considered to be qRAR $\beta 4$, based on our recent results from analysis of the structure of the qRAR $\beta$ gene ( $\mathrm{Z} \mathrm{W} \mathrm{Fu,} \mathrm{T} \mathrm{Noguchi} \mathrm{\&}$ $\mathrm{H}$ Kato, unpublished observations).

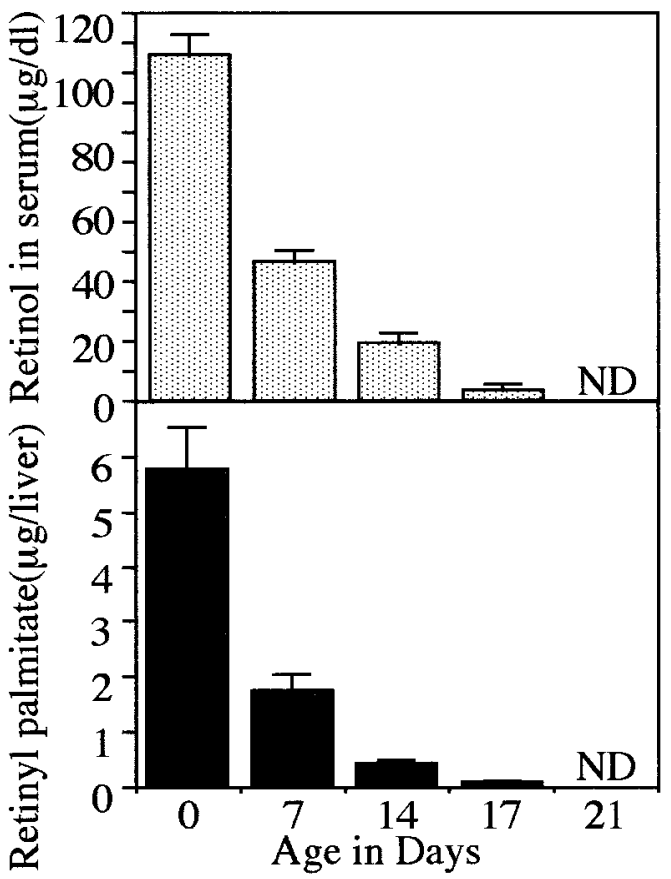

Figure 2 Depletion of VA in serum and liver of Japanese quail. One-day-old quail were fed a - VA diet, and concentrations of serum VA and hepatic retinyl palmitate were measured by HPLC as described in Materials and Methods. ND means undetected level. Data represent means \pm S.E.M. of five samples. 


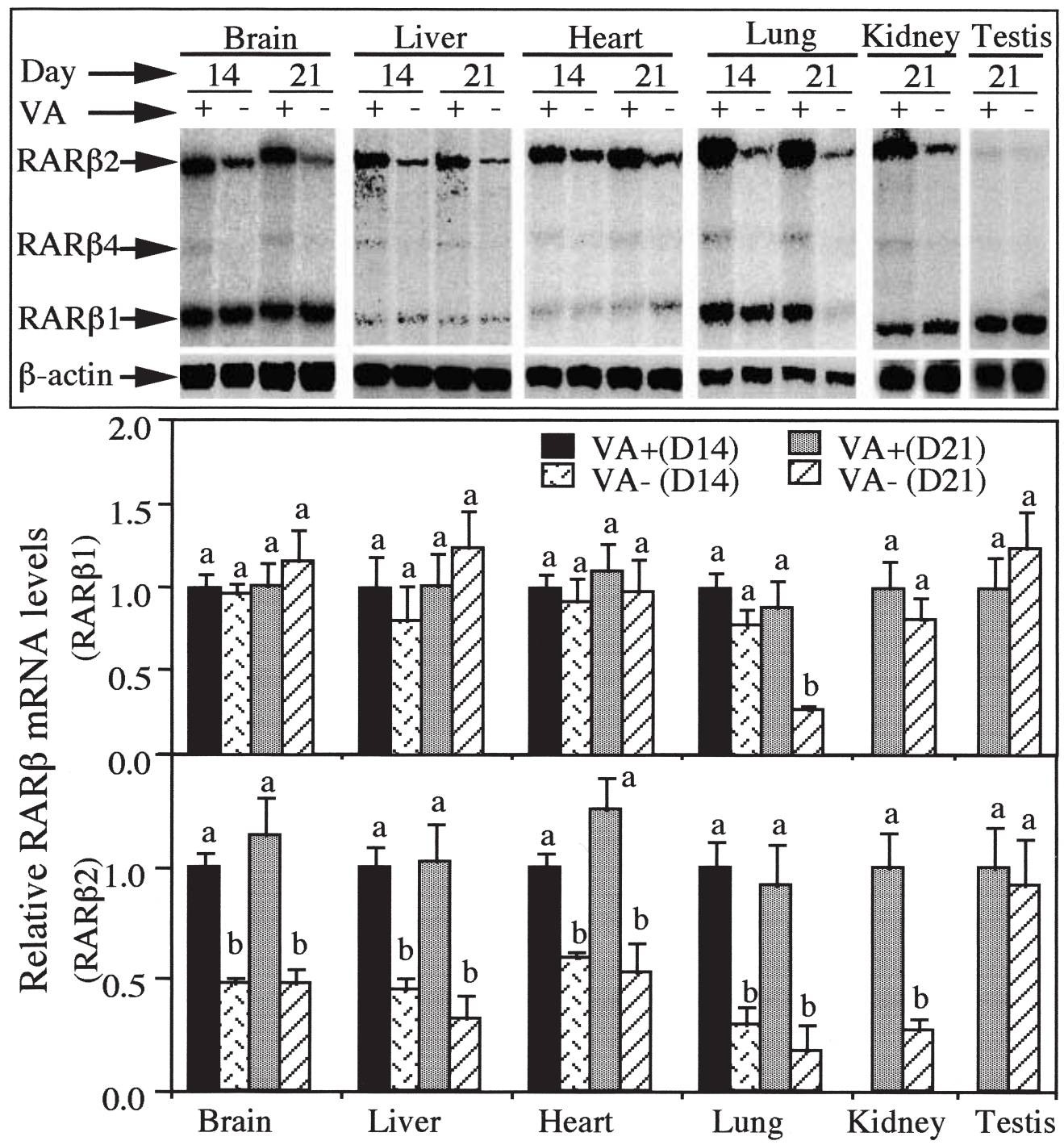

Figure 3 VA deficiency mainly reduces the expression of RAR $\beta 2$ and $\beta 4$ transcripts. One-day-old Japanese quail were fed a - VA diet or a - VA diet supplemented with VA as control. At 14 and 21 days of age, five birds from each treatment group were killed by decapitation. Representative results obtained by the lysate RNase protection assay from the selected tissues are shown in the upper panel. The quantitative representations of multiple results expressed as values relative to the abundance in the control (day 14 or 21) are presented in the lower panel. Means not having the same letters within tissues differ significantly $(P<0 \cdot 05)$.

The qRAR $\beta 1$ mRNA levels in brain, liver, heart and kidney were not affected by VA deficiency regardless of the degree of vitamin depletion. The expression of qRAR $\beta 1$ mRNA in lung, however, decreased significantly $(P<0 \cdot 05)$ in the VA-deficient group from day 14 to day 21. In contrast, expression of $\mathrm{qRAR} \beta 2 \mathrm{mRNA}$ was much more sensitive to the change of VA status. Feeding quail the - VA diet for 14 or 21 days significantly reduced the levels of qRAR $\beta 2$ mRNA in all tissues examined except testis. In the testis, however, neither the qRAR $\beta 1$ mRNA nor the qRAR $\beta 2$ mRNA level was influenced by VA deficiency. In addition, the expression of qRAR $\beta 4$
mRNA in many tissues showed a similar response to VA deficiency as seen in that of qRAR $\beta 2$ mRNA (data not shown). These results clearly indicate that VA deficiency affected the expression of qRAR $\beta$ isoform mRNAs in a tissue- and isoform-specific manner.

$R A$ rapidly induces the expression of $q R A R \beta$ isoform transcripts (Experiment 2)

Injection (i.m.) of RA $(0 \cdot 1 \mathrm{mg} / \mathrm{bird})$ for $3 \mathrm{~h}$ into the VA-deficient quail dramatically increased the levels of 

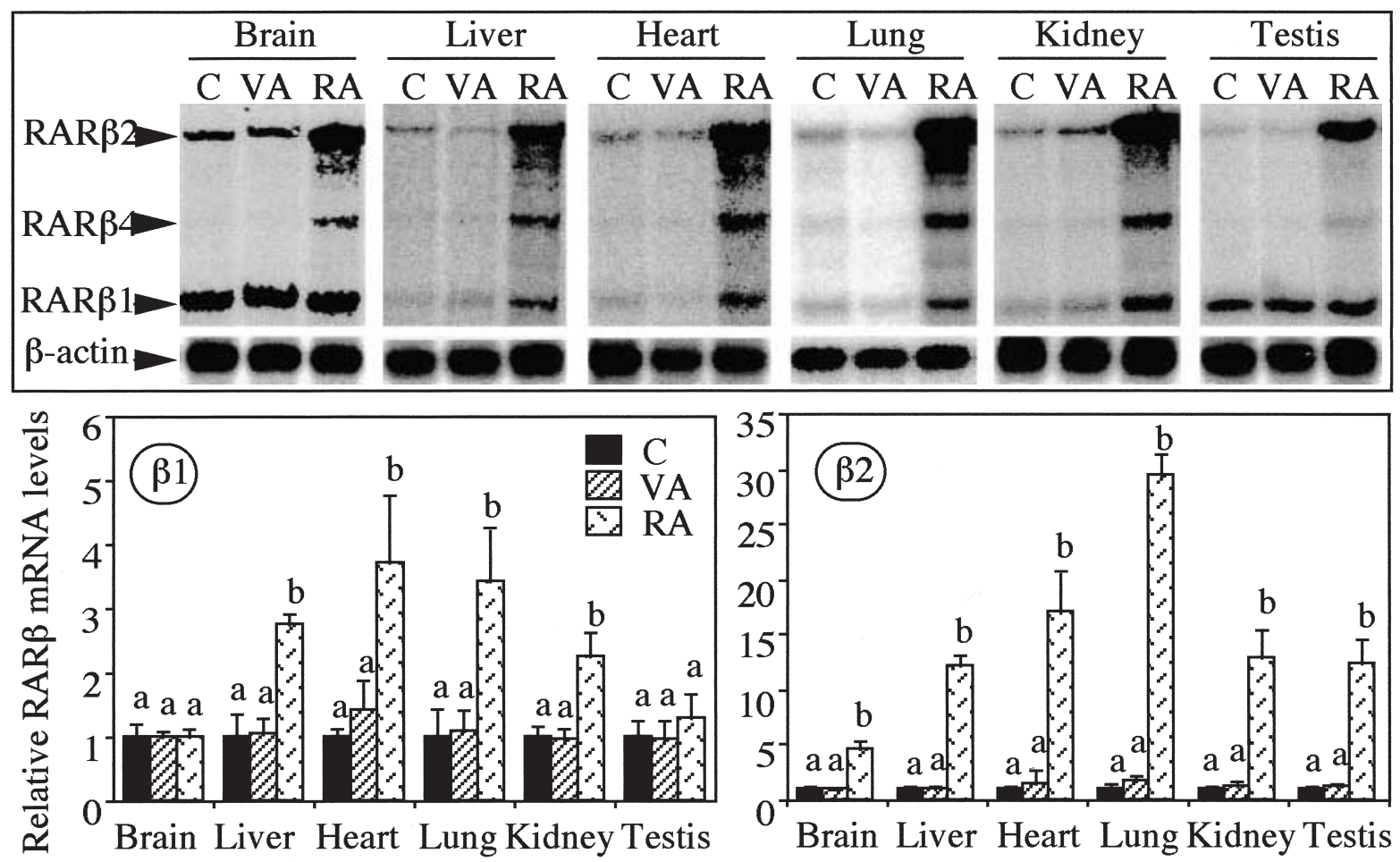

Figure 4 RA induces the expression of RAR $\beta$ isoform transcripts in a tissue-specific manner. Japanese quail were depleted of VA by feeding them a - VA diet for 3 weeks. They were killed $3 \mathrm{~h}$ after treatment with $0 \cdot 1 \mathrm{mg} / \mathrm{bird}$ of VA or RA, and their tissues were processed for measuring the expression of RAR $\beta$ isoform mRNAs by the lysate RNase protection assay. A typical result of the assay is shown in the upper panel, and the quantitative representation of multiple results expressed as values relative to the abundance in the vehicle treatment $(C)$ are presented in the lower panel. Data represent means \pm S.E.M. of five samples. Means not having a common letter are significantly different $(P<0 \cdot 05)$.

qRAR $\beta 2$ mRNA in all tissues examined, with a large variation (Fig. 4). As compared with the expression in the control quail (with vehicle injection), the expression of qRAR $\beta 2$ was increased more than 25 -fold in the lung and heart, while only a 5 -fold increase was observed in the brain. With respect to the change in the $\mathrm{qRAR} \beta 1$ expression, a tissue-specific response to the RA treatment was clearly observed (Fig. 4). Administration of RA caused a significant increase in the levels of qRAR $\beta 1 \mathrm{mRNA}$ in the lung, heart, kidney and liver, whereas no change could be detected in the brain and testis. Additionally, the expression of qRAR $\beta 4$ could also be induced by RA administration in a manner similar to that of qRAR $\beta 2$ (the upper panel of Fig. 4).

In contrast to RA treatment, administration of an equimolar amount of VA $(0 \cdot 1 \mathrm{mg} / \mathrm{bird})$ to the VAdeficient quail did not alter the levels of qRAR $\beta 1$ and $\beta 2 / 4$ mRNAs in any tissue examined after $3 \mathrm{~h}$ (Fig. 4). This might be partly due to the time lag for conversion of VA to RA, the active form of VA. To prove this hypothesis, we measured the expression of $\mathrm{qRAR} \beta$ isoform mRNAs in several tissues $8 \mathrm{~h}$ after administration of
VA or RA to the VA-deficient quail. As shown in Fig. 5, an injection of VA also induced the expression of the qRAR $\beta 2$ mRNA in the selected tissues, although the magnitude of induction was less than that by RA. Interestingly, the qRAR $\beta 1 \mathrm{mRNA}$ levels in this case were not influenced by treatment with VA after $8 \mathrm{~h}$, whereas the changes in the qRAR $\beta 1$ mRNA levels responding to the RA treatment exhibited similar tissue-specific patterns to those shown in Fig. 4.

To determine whether the inductive effect of RA on the expression of the qRAR $\beta$ isoform transcripts depends upon retinoid status, we carried out an experiment with the VA-sufficient quail that was similar to the experiment done with the VA-deficient quail. Regardless of retinoid status, an injection of RA $(0.1 \mathrm{mg} /$ bird $)$ into the VA-sufficient quail also dramatically increased the levels of both qRAR $\beta 1$ and $\beta 2$ mRNAs in the lung, and the level of qRAR $\beta 2$ mRNA in the brain (Fig. 6). The magnitude of induction was less than that seen in the VA-deficient quail, reflecting the differences in the basal mRNA levels of the two control groups (+VA vs - VA). 


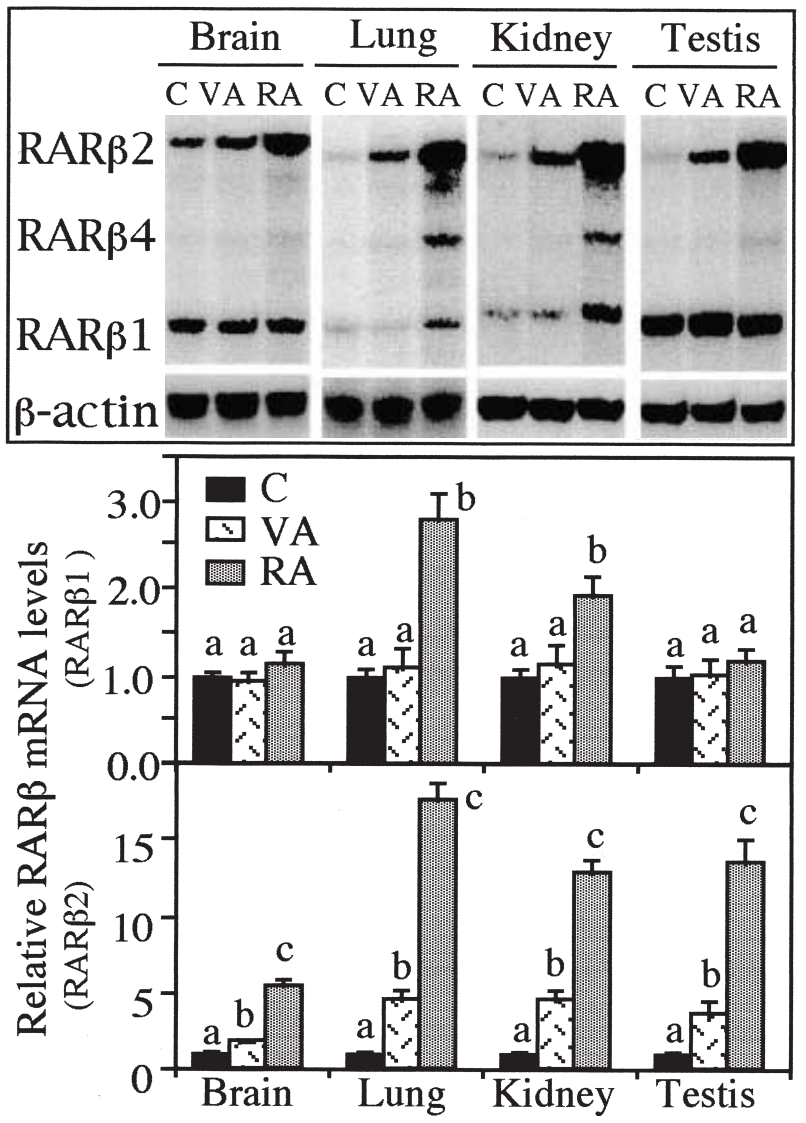

Figure 5 RA affects expression of RAR $\beta 2 / 4$ mRNA more efficiently and more quickly than VA does. Japanese quail were depleted of $\mathrm{VA}$ by feeding them a $-\mathrm{VA}$ diet for 3 weeks. They were killed $8 \mathrm{~h}$ after treatment with $0.1 \mathrm{mg} / \mathrm{bird}$ of VA or RA, their tissues were processed for measuring the expression of RAR $\beta$ mRNA by the lysate RNase protection assay. Data are shown as the relative abundance to those of the vehicle treatment (C). Data represent means \pm S.E.M. of five samples. Means not having a common letter are significantly different $(P<0 \cdot 05)$.

$R A$ induces the expression of the testis $q R A R \beta 1$ transcript in a temporal manner (Experiment 3)

In our previous study, we found that the expression of qRAR $\beta 1$ mRNAs clearly exhibits the developmental changes in the reproductive system of Japanese quail $(\mathrm{Fu}$ et al. 2001). Thus, we hypothesized that the inductive effect of RA on the expression of qRAR $\beta 1$ isoform transcript, as shown above, may differ to some extent depending on the growth stage. To elucidate this matter, we examined the effects of retinoid administration on the expression of qRAR $\beta$ isoform mRNAs in various tissues of 5- and 7-week-old quail, whose degree of sexual maturation obviously differed. At 5 weeks of age, when sexual maturation was in process and the expression of qRAR $\beta 1$ mRNA was at the maximum level, the administration of RA did not enhance the expression of

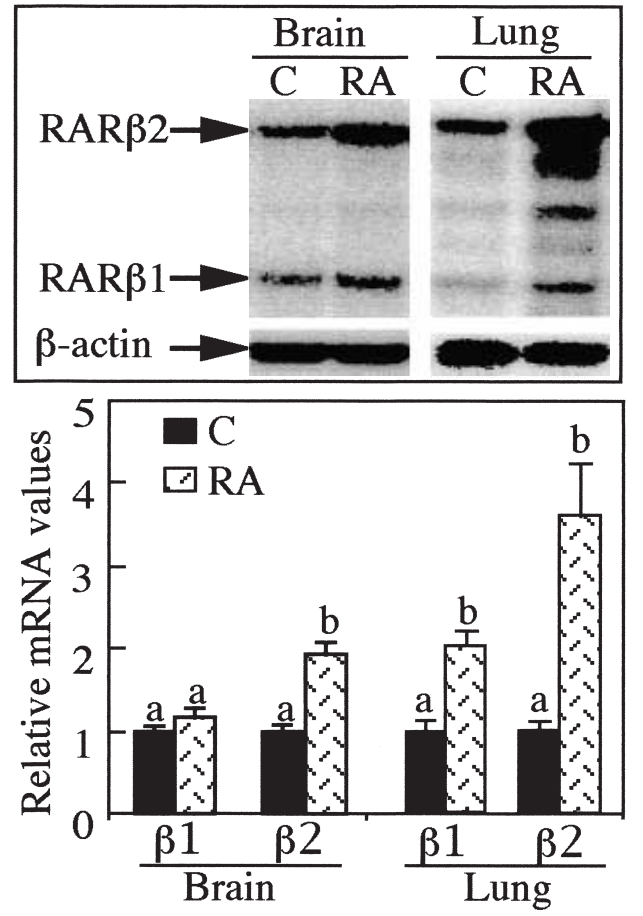

Figure 6 An excess of RA induces the overexpression of the RAR $\beta$ isoform transcripts in Japanese quail. RA $(0 \cdot 1 \mathrm{mg} / \mathrm{bird})$ was i.m. injected into the VA-sufficient quail ( 3 weeks of age). After $3 \mathrm{~h}$ these quail were killed and tissues were dissected for measuring the RAR $\beta$ isoform mRNAs by using the lysate RNase protection assay. Typical results of the assay in the brain and lung are shown in the upper panel, and the relative abundance of RAR $\beta 1$ or $\beta 2$ mRNA to that of the vehicle treatment (C) (means \pm S.E.M., $n=5$ ) respectively is shown in the lower panel. Means not having a common letter are significantly different $(P<0 \cdot 05)$.

qRAR $\beta 1$ mRNA in the testis and brain as seen in Experiment 2 (data not shown). However, administration of RA to quail at 7 weeks of age, when sexual maturation was completed and the level of qRAR $\beta 1$ mRNA in the testis lowered to about $50 \%$ of the 5 -week-old value (data not shown), significantly increased the level of the qRAR $\beta 1$ mRNA 2-fold (Fig. 7). The expression of the qRAR $\beta 1$ in the brain was still not changed at this stage (Fig. 7). These results indicate that the regulation of the qRAR $\beta 1$ transcript by RA may depend upon the developmental stage of the testis.

\section{Discussion}

Feeding 1-day-old quail the - VA diet caused rapid decreases in the levels of both serum VA and hepatic retinyl palmitate, and consequently reduced the growth rate. To elucidate the physiological changes underlying the alteration of VA status in birds, we examined the expression of $\operatorname{RAR} \beta$ gene in the various tissues of both 

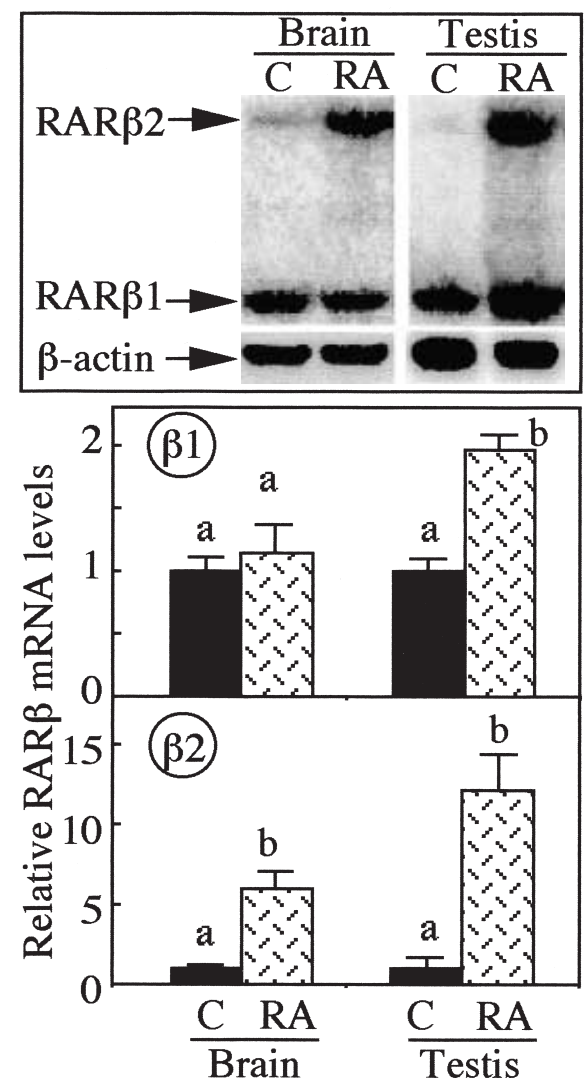

Figure 7 RA affects the expression of RAR $11 \mathrm{mRNA}$ in a stage-specific manner in the testis. Japanese quail were depleted of VA by feeding them a - VA diet for 2 weeks, - VA supplemented with RA for 4 weeks, and then - VA for 1 week. These quail were killed $3 \mathrm{~h}$ after they were administered $0.1 \mathrm{mg} / \mathrm{bird}$ of RA or the vehicle (as control, C), and their tissues were processed for assaying RAR $\beta$ mRNA. Typical results in the brain and testis are shown in the upper panel. The relative abundance of RAR $\beta 1$ or $\beta 2 \mathrm{mRNA}$ to that of the control group (means \pm S.E.M., $n=5$ ) is shown in the lower panel. Means not having a common letter are significantly different $(P<0 \cdot 05)$.

normal and VA-deficient quail, before and after retinoid administration, since RAR $\beta$ has been thought to be involved in the retinoid signal transduction pathways in mammals (Lohnes et al. 1993, 1994, Lufkin et al. 1993, Mendelsohn et al. 1994b).

The results presented here clearly indicate that retinoid nutritional status specifically modulates the expression of each qRAR $\beta$ isoform transcript. VA deficiency significantly reduced the expression of $\mathrm{qRAR} \beta 2$ and $\beta 4$ mRNAs in the tissues examined except testis, whereas the levels of the qRAR $\beta 1$ transcript in these tissues were almost unchanged. The absence of the effect of VA deficiency in the testis qRAR $\beta 2$ mRNA might be partly due to the lower level of this isoform expressed in this tissue. Thus, these results strongly indicate that $\mathrm{RAR} \beta 2$ and $\beta 4$ rather than $\beta 1$ is VA-dependent during quail growth. Previously, several research groups (Ul-Haq et al. 1991, Kato et al. 1992, Verma et al. 1992, Gaemers et al. 1997) have shown that the expression of RAR $\beta$ is greatly reduced in many VA-deficient rat or mouse tissues. However, those groups described only the effect of VA deficiency on the expression of the pan-RAR $\beta$ transcripts, without addressing the question of which mRNA isoforms were more susceptible to VA deficiency. Our present results clearly demonstrate for the first time that the expression of RAR $\beta 1$ in intact animals is regulated differently by VA than is the expression of RAR $\beta 2$ and $\beta 4$. In addition, both qRAR $\beta 1$ and $\beta 2$ mRNAs decreased in the VA-deficient lung, in agreement with the results for the lung of VA-deficient rats (Takeyama et al. 1996) and those for VA-deficient quail embryos (Kostetskii et al. 1996). Taken together, these results clearly indicate that VA regulates the expression of $\mathrm{RAR} \beta$ isoform transcripts in an isoform-specific manner, and also in a tissue-specific manner.

The effect of VA deficiency on the levels of RAR $\beta$ expression was transiently reversed by the administration of RA. A single dose of RA to the VA-deficient quail rapidly increased the levels of the qRAR $\beta 2$ mRNA in all tissues examined. In the case of the qRAR $\beta 1$ mRNA, however, the inductive effect of RA was exhibited in a tissue-specific manner. RA could induce the expression of the qRAR $\beta 1$ in the liver, heart, lung and kidney, while no change was observed in the levels of qRAR $\beta 1 \mathrm{mRNA}$ in the brain and testis. These results further confirmed that RAR $\beta 2$ is more sensitive to changes in retinoid status. Similar induction of RAR $\beta$ transcripts has been characterized in mammalian tissues (Kato et al. 1992, Gaemers et al. 1997) and in several cell lines (Clifford et al. 1990, Hu \& Gudas 1990, Zelent et al. 1991). Moreover, we have shown that administration of RA to the control (VAsufficient) quail resulted in the overexpression of the $\operatorname{RAR} \beta$ gene. This rapid increase in the $\operatorname{RAR} \beta$ mRNA levels in the tissues of whole animals by RA treatment, together with the down-regulation of the qRAR $\beta$ transcripts in the tissues of VA-deficient quail, suggests an important role for $\operatorname{RAR} \beta$ in mediating the physiological actions of VA in Japanese quail.

The magnitude of induction of $\operatorname{RAR} \beta$ isoforms by the RA treatment seemed to be higher in the more highly vascularized tissues such as liver, heart and lung (Fig. 4). Thus, this could raise the possibility that the tissue-specific changes in RAR $\beta$ isoforms are due to variations in blood cell components or vascularization among different tissues. In our sampling protocol, quail were killed by decapitation, and bled as completely as possible before the tissues were dissected. It has been reported that the expected yield of total RNA from the animal blood cell is far lower than that from any tissue (for example, about 15-20 $\mu \mathrm{g} / \mathrm{ml}$ of whole blood vs $6-10 \mathrm{mg} / \mathrm{g}$ of liver). Moreover, we have 
found that each $\mathrm{qRAR} \beta$ isoform was almost not expressed in the quail blood cells, and that the RA treatment could not induce their expression (data not shown). In addition, we have also found that the level of each qRAR $\beta$ isoform mRNA in blood vessels including aorta, pulmonary trunk and superior and inferior vena cava was not higher than those in the heart or lung, and that the inductive magnitude in the blood vessel by the treatment of RA was not greater than those observed in either heart or lung (data not shown). From these results, the possibility mentioned above seems to be low.

In this study, we also examined the influence of VA on $\operatorname{RAR} \beta$ gene expression. Compared with RA, an equimolar amount of VA was not able to induce the expression of each qRAR $\beta$ isoform transcript $3 \mathrm{~h}$ after administration to the VA-deficient quail. However, a significant increase was observed $8 \mathrm{~h}$ after administration of VA, although the inductive magnitude was lower than that of RA treatment. These results indicated that the induction of $\operatorname{RAR} \beta$ gene expression by VA is delayed and less strong than that by RA. Several comparable results were also reported in mammals (Kato et al. 1992, Van Pelt et al. 1992, Gaemers et al. 1997). These results suggest that the delay and weak effect may be partly due to the time lag for the conversion of VA to RA, or partly due to differences in peak RA exposure caused by differences in metabolite transport or delivery kinetics to target organs. Recently we have found that when Japanese quail were fed diets depleted of VA but supplemented with RA the growth of their testes was faster than in VA-fed controls ( $\mathrm{Fu}$ et al. 1997b). Furthermore, we also observed that RA exerts the same effect on the maturation of the female reproductive system in Japanese quail as it does in the male (Fu et al. 2000). In addition, we have found that RA is easily taken up by the testis of Japanese quail (Fu et al. 1997b), in contrast to the case with mammalian reproductive organs (Kurlandsky et al. 1995). Taken together, these results suggested that the accelerative effects of RA on the maturation of the reproductive organs in quail may be an action of RA through its nuclear receptors to alter the expression of genes that relate to sexual maturation.

It has been reported that $\operatorname{RAR} \beta 1$ and $\operatorname{RAR} \beta 2 / 4$ are generated by the use of two different promoters in mammals (Zelent et al. 1991, Mendelsohn et al. 1994a). RA response element (RARE) has been identified in the promoter region of mouse RAR $\beta 2 / 4$ (Zelent et al. 1991), whereas no RARE exists in the RAR $\beta 1$ promoter region (Mendelsohn et al. 1994a). In vitro study has shown that RA modulation of $\mathrm{RAR} \beta 2 / \beta 4$ transcripts is achieved at the level of transcriptional initiation via RARE present in the $\operatorname{RAR} \beta 2 / \beta 4$ promoter (Mendelsohn et al. 1991). In contrast, RAR $\beta 1$ promoter activity is not modified by RA treatment, and the RA-induced accumulation of RAR $\beta 1$ transcript may occur via an RA-dependent release of a block in RNA chain elongation (Mendelsohn et al. 1994a). We recently analyzed the structure of the qRAR $\beta$ gene and found that the DNA sequence of the qRAR $\beta 2 / 4$ $5^{\prime}$-untranslated region was highly conserved compared with that in human and mouse RAR $\beta 2 / 4$. Furthermore, RARE and a TATA box also existed in the qRAR $\beta 2 / 4$ promoter region ( $Z$ W Fu, T Noguchi \& $\mathrm{H}$ Kato, unpublished observations), as is seen in mammals. Therefore, the differences of $\operatorname{RAR} \beta 1$ and $\beta 2 / 4$ transcripts in their responses to changes in retinoid status might be due to the use of different promoters in the $\mathrm{qRAR} \beta$ gene.

An additional interesting observation reported here is that the inductive effect of RA on the testis $\mathrm{qRAR} \beta 1$ transcript depended upon the growth stage. RA could not induce the expression of testis $\mathrm{qRAR} \beta 1$ transcript at 5 weeks of age, while it caused a 2 -fold increase at 7 weeks of age. Meanwhile, the level of the qRAR $\beta 1$ transcript decreased by about 2 -fold during this period of testicular development, which is in agreement with our previous result (Fu et al. 2001). These results mean that the RA-induced accumulation of the testis qRAR $\beta 1$ transcript was almost equal to the decreased amount, which occurred during testicular maturation. Moreover, the absence of the inductive effect of RA on the brain qRAR $\beta 1$ transcript at any developmental stage examined might be due to the constant expression of this isoform throughout the whole development ( $\mathrm{Fu}$ et al. 2001). Therefore, from these results we hypothesize that retinoid treatment has an inductive effect only when the RAR $\beta 1 \mathrm{mRNA}$ level is below the maximum.

Analysis of RAR $\beta$ gene structure in mammals further suggested that the $5^{\prime}$-untranslated region is involved in the tissue-specific expression of this gene (Zelent et al. 1991, Mendelsohn et al. 1994a, Zimmer et al. 1994). Therefore, further analysis of the qRAR $\beta$ gene structure will surely help the understanding of the mechanism underlying the effect of retinoid status on the tissue-specific expression of each isoform.

In conclusion, the present study clearly demonstrates the diverse regulation of RAR $\beta$ isoforms by VA nutritional status in the quail and suggests distinct roles for the $\operatorname{RAR} \beta$ isoforms in the physiological actions of VA.

\section{Acknowledgements}

The Japan Society for Promotion of Science (JSPS) is greatly acknowledged for providing a postdoctoral fellowship to Z W F. We also wish to thank Mr Teruo Ebihara (Ebihara Japanese Quail Farm, Tochigi, Japan) for the gift of 1-day-old male quail. This work was supported partly by a grant-in-aid for Exploratory Research (No. 9876071) and by a grant-in-aid for JSPS Fellows (No. 98218) from the Ministry of Education, Science, Sports and Culture of Japan. 


\section{References}

Akmal KM, Dufour JM, Vo M, Higginson S \& Kim KH 1998 Ligand-dependent regulation of retinoic acid receptor alpha in rat testis: in vivo response to depletion and repletion of vitamin A. Endocrinology 139 1239-1248.

Clifford JL, Petkovich M, Chambon P \& Lotan R 1990 Modulation by retinoids of mRNA levels for nuclear retinoic acid receptors in murine melanoma cells. Molecular Endocrinology 4 1546-1555.

Evans RM 1988 The steroid and thyroid hormone receptor superfamily. Science 240 889-895.

Fu ZW, Kubo T \& Kato H 1997a Analyses of serotonin $\mathrm{N}$-acetyltransferase mRNA content in rat pineal gland and testis by an improved assay system - micro lysate protection assay. Animal Science and Technology (Japan) 68 893-896.

Fu ZW, Ohara S, Kato H, Sugahara K \& Kubo T $1997 b$ Retinoic acid accelerates the testicular maturation in Japanese quail. Animal Science and Technology (Japan) 68 420-422.

Fu ZW, Kato H, Sugahara K \& Kubo T 1998 Vitamin A deficiency reduces the responsiveness of pineal gland to light in Japanese quail (Coturnix japonica). Comparative Biochemistry and Physiology 119A 593-598.

Fu ZW, Kato H, Kotera N, Sugahara K \& Kubo T 1999 Regulation of the expression of serotonin $\mathrm{N}$-acetyltransferase gene in Japanese quail (Coturnix japonica): II. Effect of vitamin A deficiency. Journal of Pineal Research 27 34-41.

Fu ZW, Kato H, Sugahara K \& Kubo T 2000 Retinoic acid accelerates the development of reproductive organs and egg production in Japanese quail (Coturnix coturnix japonica). Biology of Reproduction 63 1805-1810.

Fu ZW, Kubo T, Sugahara K, Noguchi T \& Kato H 2001 Cloning of complementary deoxyribonucleic acids encoding quail (Coturnix coturnix japonica) retinoic acid receptor $\beta$ isoforms and changes in their gene expression during gonadotropic growth. Biology of Reproduction 64 231-241.

Gaemers IC, Van Pelt AM, Van der Saag PT, Hoogerbrugge JW, Themmen AP \& de Rooij DG 1997 Effect of retinoid status on the messenger ribonucleic acid expression of nuclear retinoid receptors alpha, beta, and gamma, and retinoid X receptors alpha, beta, and gamma in the mouse testis. Endocrinology 138 1544-1551.

Giguerre V, Ong ES, Segui P \& Evans RM 1987 Identification of a receptor for the morphogen retinoic acid. Nature $330624-629$.

Heyman RA, Mangelsdorf DJ, Dyck JA, Stein RB, Eichele G, Evans RM \& Thaller C 1992 9-cis retinoic acid is a high affinity ligand for the retinoid X receptor. Cell 68 397-406.

Hu L \& Gudas LJ 1990 Cyclic AMP analogs and retinoic acid influence the expression of retinoic acid receptor alpha, beta, and gamma mRNAs in F9 teratocarcinoma cells. Molecular and Cellular Biology 10 391-396.

Kastner P, Krust A, Mendelsohn C, Garnier JM, Zelent A, Leroy P, Staub A \& Chambon P 1990 Murine isoforms of retinoic acid receptor gamma with specific patterns of expression. PNAS $\mathbf{8 7}$ 2700-2704

Kastner P, Mark M, Leid M \& Gansmuller A 1996 Abnormal spermatogenesis in RXR- $\beta$ mutant mice. Genes and Development 10 80-92.

Kato H, Fu ZW, Kotera N, Sugahara K \& Kubo T 1999 Regulation of the expression of serotonin $\mathrm{N}$-acetyltransferase gene in Japanese quail (Coturnix japonica): I. Rhythmic pattern and effect of light. Journal of Pineal Research 27 24-33.

Kato S, Mano H, Kumazawa T, Yoshizawa Y, Kojima R \& Masushige S 1992 Effect of retinoid status on alpha, beta and gamma retinoic acid receptor $\mathrm{mRNA}$ levels in various rat tissues. Biochemical Journal 286 755-760.

Kostetskii I, Linask KK \& Zile MH 1996 Vitamin A deficiency and the expression of retinoic acid receptors during early cardiogenesis in quail embryo. Roux's Archives of Developmental Biology 205 260-271.
Kurlandsky SB, Gamble MV, Ramakrishnan R \& Blaner WS 1995 Plasma delivery of retinoic acid to tissues in the rat. Journal of Biological Chemistry 270 17850-17857.

Leroy P, Krust A, Zelent A, Mendelsohn C, Garnier JM, Kastner P, Dierich A \& Chambon P 1991 Multiple isoforms of the mouse retinoic acid receptor alpha are generated by alternative splicing and differential induction by retinoic acid. EMBO Journal 10 59-69.

Levin AA, Sturzenbecker LJ, Kazmer S, Bosakowski T, Huselton C, Allenby G, Speck J, Kratzeisen C, Rosenberger M, Lovey A \& Grippo JF 1992 9-cis retinoic acid stereoisomer binds and activates the nuclear receptor RXR alpha. Nature 355 359-361.

Lohnes D, Kastner P, Dierich A, Mark M, LeMeur M \& Chambon P 1993 Function of retinoic acid receptor gamma in the mouse. Cell 73 643-658.

Lohnes D, Mark M, Mendelsohn C, Dolle P, Dierich A, Gorry P, Gansmuller A \& Chambon P 1994 Function of the retinoic acid receptors (RARs) during development (I). Craniofacial and skeletal abnormalities in RAR double mutants. Development $\mathbf{1 2 0}$ $2723-2748$.

Lufkin T, Lohnes D, Mark M, Dierich A, Gorry P, Gaub MP, LeMeur M \& Chambon P 1993 High postnatal lethality and testis degeneration in retinoic acid receptor alpha mutant mice. PNAS 90 $7225-7229$.

Matsumura Y, Domeki M, Sugahara K, Kubo T Jr, Roberts CT, LeRoith D \& Kato H 1996 Nutritional regulation of insulin-like growth factor-I receptor mRNA levels in growing chickens. Bioscience, Biotechnology and Biochemistry 60 979-982.

Mendelsohn C, Ruberte E, LeMeur M, Morriss-Kay G \& Chambon P 1991 Developmental analysis of the retinoic acid-inducible RAR-beta 2 promoter in transgenic animals. Development 113 723-734.

Mendelsohn C, Larkin S, Mark M, LeMeur M, Clifford J, Zelent A \& Chambon P 1994a RAR beta isoforms: distinct transcriptional control by retinoic acid and specific spatial patterns of promoter activity during mouse embryonic development. Mechanisms of Development 45 227-241.

Mendelsohn C, Lohnes D, Decimo D, Lufkin T, LeMeur M, Chambon P \& Mark M 1994b Function of the retinoic acid receptors (RARs) during development (II). Multiple abnormalities at various stages of organogenesis in RAR double mutants. Development 120 2749-2771.

Petkovich M, Brand NJ, Krust A \& Chambon P 1987 A human retinoic acid receptor which belongs to the family of nuclear receptors. Nature 330 444-450.

Takeyama K, Kojima R, Ohashi R, Sato T, Mano H, Masushige S \& Kato S 1996 Retinoic acid differentially up-regulates the gene expression of retinoic acid receptor alpha and gamma isoforms in embryo and adult rats. Biochemical and Biophysical Research Communications 222 395-400.

Ul-Haq R, Pfahl M \& Chytil F 1991 Retinoic acid affects the expression of nuclear retinoic acid receptors in tissues of retinoldeficient rats. PNAS 88 8272-8276.

Underwood B 1984 Vitamin A in animal and human nutrition. In The Retinoids, vol 1, pp 281-392. Eds MB Sporn, AB Robert \& DS Goodmen. New York: Academic Press.

Van Pelt AM, Van den Brink CE, de Rooij DG \& Van der Saag PT 1992 Changes in retinoic acid receptor messenger ribonucleic acid levels in the vitamin A-deficient rat testis after administration of retinoids. Endocrinology 131 344-350.

Verma AK, Shoemaker A, Simsiman R, Denning M \& Zachman RD 1992 Expression of retinoic acid nuclear receptors and tissue transglutaminase is altered in various tissues of rats fed a vitamin A-deficient diet. Journal of Nutrition 122 2144-2152.

Wilson JG, Roth CB \& Warkany J 1953 An analysis of the syndrome of malformations induced by maternal vitamin A deficiency. Effects of restoration of vitamin A at various times during gestation. American Journal of Anatomy 92 189-217. 
Wolbach SB \& Howe PR 1925 Tissue changes following deprivation of fat-soluble A vitamin. Journal of Experimental Medicine $\mathbf{4 3}$ 753-777.

Zelent A, Mendelsohn C, Kastner P, Krust A, Garnier JM, Ruffenach F, Leroy P \& Chambon P 1991 Differentially expressed isoforms of the mouse retinoic acid receptor beta generated by usage of two promoters and alternative splicing. EMBO Journal 10 71-81.
Zimmer A, Zimmer AM \& Reynolds K 1994 Tissue specific expression of the retinoic acid receptor-beta 2: regulation by short open reading frames in the $5^{\prime}$-noncoding region. Journal of Cell Biology 127 1111-1119.

Received 29 December 2000 Accepted 19 January 2001 